\title{
IL-5 and IL-5 Receptor in Asthma
}

\author{
ATC Kotsimbos, Q Hamid ${ }^{+}$
}

\begin{abstract}
Department of Medicine, Meakins-Christie Laboratories, McGill University, 3626 rue St Urbain, Montreal, Quebec, Canada H2X 2P2
\end{abstract}

Eosinophils, along with mast cells are key cells involved in the innate immune response against parasitic infection whereas the adaptive immune response is largely dependent on lymphocytes. In chronic parasitic disease and in chronic allergic disease, IL-5 is predominantly a T cell derived cytokine which is particularly important for the terminal differentiation, activation and survival of committed eosinophil precursors. The human IL-5 gene is located on chromosome 5 in a gene cluster that contains the evolutionary related IL-4 family of cytokine genes. The human IL-5 receptor complex is a heterodimer consisting of a unique $\alpha$ subunit (predominantly expressed on eosinophils) and a $\beta$ subunit which is shared between the receptors for IL-3 \& GM-CSF (more widely expressed). The $\alpha$ subunit is required for ligand-specific binding whereas association with the $\beta$ subunit results in increased binding affinity. The alternative splicing of the $\alpha I L-5 R$ gene which contains 14 exons can yield several $\alpha I L-5 R$ isoforms including a membrane-anchored isoform $(\alpha I L-5 R m)$ and a soluble isoform ( $\alpha I L-5 R s)$. Cytokines such as IL-5 produce specific and non-specific cellular responses through specific cell membrane receptor mediated activation of intracellular signal transduction pathways which, to a large part, regulate gene expression. The major intracellular signal transduction mechanism is activation of non-receptor associated tyrosine kinases including JAK and MAP kinases which can then transduce signals via a novel family of transcriptional factors named signal transducers and activators of transcription (STATS). JAK2, STAT1 and STAT 5 appear to be particularly important in IL-5 mediated eosinophil responses.

Asthma is characterized by episodic airways obstruction, increased bronchial responsiveness, and airway inflammation. Several studies have shown an association between the number of activated $T$ cells and eosinophils in the airways and abnormalities in FEV1, airway reactivity and clinical severity in asthma. It has now been well documented that IL-5 is highly expressed in the bronchial mucosa of atopic and intrinsic asthmatics and that the increased IL-5 mRNA present in airway tissues is predominantly $T$ cell derived. Immunocytochemical staining of bronchial biopsy sections has confirmed that IL$5 \mathrm{mRNA}$ transcripts are translated into protein in asthmatic subjects. Furthermore, the number of activated CD $4+T$ cells and IL-5 mRNA positive cells are increased in asthmatic airways following antigen challenge and studies that have examined IL-5 expression in asthmatic subjects before and after steroids have shown significantly decreased expression following oral corticosteroid treatment in steroid-sensitive asthma but not in steroid resistant and chronic severe steroid dependent asthma. The link between T cell derived IL-5 and eosinophil activation in asthmatic airways is further strengthened by the demonstration that there is an increased number of $\alpha I L-5 R \mathrm{mRNA}$ positive cells in the bronchial biopsies of atopic and non-atopic asthmatic subjects and that the eosinophil is the predominant site of this increased $\alpha I L-5 R$ mRNA expression. We have also shown that the subset of activated eosinophils that expressed mRNA for membrane bound $\alpha$ IL5r inversely correlated with FEVI, whereas the subset of activated eosinophils that expressed mRNA for soluble $\alpha I L 5 r$ directly correlated with FEV1. Hence, not only does this data suggest that the presence of eosinophils expressing $\alpha I L-5 R$ mRNA contribute towards the pathogenesis of bronchial asthma, but also that the eosinophil phenotype with respect to $\alpha I L-$ $5 R$ isoform expression is of central importance. Finally, there are several animal, and more recently in vitro lung explant, models of allergen induced eosinophilia, late airway responses(LARS), and bronchial hyperresponsiveness (BHR) - all of which support a link between IL-5 and airway eosinophila and bronchial hyperresponsiveness. The most direct demonstration of $T$ cell involvement in LARS is the finding that these physiological responses can be transferred by CD4+ but not CD8+T cells in rats. The importance of IL-5 in animal models of allergen induced bronchial hyperresponsiveness has been fur-

\footnotetext{
Supported by MRC Canada and JT Costello Memorial Research fund.

${ }^{+}$Corresponding author. Fax: +514-398-7483. E-mail:

Hamid@meakins.lan.mcgill.ca

Received 3 September 1997

Accepted 30 September 1997
} 
ther demonstrated by a number of studies which have indicated that IL-5 administration is able to induce late phase responses and BHR and that anti-IL-5 antibody can block allergen induced late phase responses and BHR.

In summary, activated T lymphocytes, IL5 production and eosinophil activation are particularly important in the asthmatic response. Human studies in asthma and studies in allergic animal models have clearly emphasised the unique role of IL-5 in linking T lymphocytes and adaptive immunity, the eosinophil effector cell, and the asthma phenotype. The central role of activated lymphocytes and eosinophils in asthma would argue for the likely therapeutic success of strategies to block T cell and eosinophil activation (eg steroids). Importantly, more targeted therapies may avoid the complications associated with steroids. Such therapies could target key T cell activation proteins and cytokines by various means including blocking antibodies (eg anti-CD4, anti-CD40, anti-IL-5 etc), antisense oligonucleotides to their specific mRNAs, and/or selective inhibition of the promoter sites for these genes. Another option would be to target key eosinophil activation mechanisms including the $\alpha I L 5 r$. As always, the risk to benefit ratio of such strategies await the results of well conducted clinical trials.

Key words: interleukin 5 - asthma - eosinophils

\section{ASTHMA AND ALLERGIC INFLAMMATION}

Asthma is characterized by episodic airway obstruction, increased bronchial responsiveness to the inhalation of non-specific irritants and airway inflammation (McFadden \& Gilbert 1992). The link between abnormal airway physiology and airway inflammation was initially suggested by the results of post-mortem studies of asthmatic lungs which documented the presence of an inflammatory infiltrate (Dunnill 1960). The use of fibreoptic bronchoscopy has allowed bronchial biopsies and lavage fluid to be examined in less severe asthmatics and in normal subjects. These studies have shown that eosinophils and T lymphocytes in particular are increased in number and activation status in asthmatic airways compared to controls (Jeffery et al. 1989, Azzawi et al. 1990, Bradley et al.1991, Bentley et al. 1992, Laitinen et al. 1993). Furthermore, several studies have correlated the number of activated $\mathrm{T}$ cells and eosinophils with abnormalities in FEV1 and airway reactivity (Walker et al. 1991) and with clinical severity in asthma (Bousquet et al. 1990).

More recently, lung resection studies have also demonstrated an increase in the number of eosinophils and $\mathrm{T}$ lymphocytes in both the large and small airways of asthmatic subjects compared to nonasthmatic controls matched for age, sex, smoking history, lung function and airway size (Hamid et al. 1996). These results extend the findings from previous studies using endobronchial biopsies by showing that a similar but more severe inflammatory process is present in the peripheral airways and in the airway wall external to the smooth muscle layer-both of which are not routinely biopsied during fibreoptic bronchoscopy. This data is consistent with the evidence that suggests that the small airways are the major site of obstruction in asthma (Macklem et al. 1970, Wiggs et al. 1992, Kuwano et al. 1993). In addition, the extensive presence of inflammatory cells throughout the airways makes it possible that these cells may be important modulators of the function of other cells present in airway tissues-including epithelial cells, fibroblasts and smooth muscle cells. There is therefore considerable interest and research into the mechanisms underlying the initiation and maintenance of the inflammatory respone in asthmawhich is likely to be a consequence of a complicated interaction between various cells and mediators.

\section{IL-5: AN IMPORTANT LINK BETWEEN T CELLS AND EOSINOPHILS}

\section{IL-5 MOLECULAR BIOLOGY \\ IL-5 GENE, MRNA AND PROTEIN}

The human IL-5 gene is located on chromosome 5 in a gene cluster that contains the IL-4 family of cytokine genes (Boulay \& Paul 1992). It contains 4 exons which encode a peptide of 124 amino acids (Azuma et al. 1986 ). IL-5 is a monomer which exists functionally as an antiparallel homodimeric glycoprotein linked by 2 disulfide bonds and has a tertiary crystalline structue consisting of 4 alpha helices (Milburn et al. 1993). The exon structure, primary secondary and tertiary protein sequences, cell membrane receptors and intracellular signal transduction pathways of IL-5 are similar with those from the IL-4 cytokine family, thereby suggesting that they are evolutionary related cytokines (Milburn et al. 1993, Kosugi et al. 1995). Therefore, it is not surprising that these cytokines also share cellular sources and functional activities and are all important in the co-ordinated immune defense against parasitic infection. However, IL-5 is unusual in that it is the most highly conserved member of this group. In addition, the IL-5 glycoprotein is highly homolo- 
gous between mammalian species thereby suggesting that IL-5 function is of particular benefit to the host organism.

\section{IL-5 RECEPTOR GENE, MRNA AND PROTEIN}

The human IL-5 receptor complex is a heterodimer consisting of a unique $\alpha$ subunit ( $\alpha$ IL5R; MW 60Kd) and a $\beta$ subunit (MW 130Kd) which is shared between the receptors for IL-3 and GM-CSF (Lopez et al. 1991, Murata et al. 1992, Miyajima et al. 1993). In vitro, the expression of human $\alpha I L-5 R$ has been described to be present on eosinophils and basophils whereas the $\beta$ subunit is more widely expressed (Denburg et al. 1991, Migita et al.1991, Miyajima et al. 1993). The $\alpha$ subunit is required for ligand-specific binding whereas association with the $\beta$ subunit results in increased binding affinity (Takagi et al. 1995). The receptors for IL-5, IL-3 and GM-CSF belong to the class I cytokine receptor family based on their structural motifs (Bazan 1990, Boulay \& Paul, $1992 b)$. The membrane proximal region of the extracellular domains of both the $\alpha$ and $\beta$ subunits of the IL-5R have common structural features which they share with the other members of the haematopoietin cytokine receptor family. This homologous region is characterized by a trp-ser-xtrp-ser motif and by several conserved short sequence elements - the integrity of which is required for the interaction with its ligand (Bazan 1990, Boulay \& Paul 1992b).

The gene for human $\alpha \mathrm{IL}-5 \mathrm{R}$ is located on chromosome 3 (Tuypens et al. 1992) and the gene for human $\beta I L-5 R$ is on chromosome 22 (Miyajima et al. 1993, Takai et al. 1994). The alternative splicing of the $\alpha \mathrm{IL}-5 \mathrm{R}$ gene which contains 14 exons can yield several $\alpha$ IL-5R isoforms including a membrane-anchored isoform ( $\alpha \mathrm{IL}-5 \mathrm{Rm})$ and a soluble isoform ( $\alpha$ IL-5Rs) (Tuypens et al. 1992, Tavernier et al. 1992). The membranous and soluble $\alpha \mathrm{IL}-5 \mathrm{R}$ isoform primarily differ in whether or not a transmembrane binding domain is present. Although, $\alpha$ IL-5Rm and $\alpha$ IL-5Rs isoform bind IL5 with equally high affinity (Tavernier et al. 1992, Devos et al. 1993, Koike et al. 1994), $\alpha$ IL-5Rm interacts with the $\beta$ subunit thereby substantially increasing the affinity for IL-5 and allowing specific signal transduction pathways to be activated (Koike et al. 1994) whereas $\alpha$ IL-5Rs competes for IL-5 ligand with $\alpha$ IL-5Rm present on eosinophils and therefore has antagonistic properties that may have a regulatory role (Tavernier et al. 1991).

\section{IL-5 RECEPTOR MEDIATED INTRACELLULAR SIGNAL TRANSDUCTION}

Cytokines produce specific and non-specific cellular responses through receptor mediated acti- vation of intracellular signal transduction pathways which, to a large part, regulate gene expression (Nicola et al. 1989, Miyajima et al. 1992). IL-5R mediated signalling requires the cytoplasmic domains of both subunits, is dependent on the proline rich areas proximal to the transmembrane domains and involves the process of dimerization of the $\alpha$ and $\beta$ subunits (Sakamaki et al. 1992, Miyajima et al. 1992, Takaki et al. 1993). The major intracellular signal transduction mechanism is activation of non-receptor associated tyrosine kinases including MAP kinases (Matsumoto et al. 1995, Pazdrak et al. 1995) and JAKS (Sakamaki et al. 1992, Corneils et al. 1995) which can then transduce signals via a novel family of transcriptional factors named signal transducers and activators of transcription (STATS) (Ihle et al. 1995a,b). STAT proteins exist in the cytoplasm as latent, transcriptionally inactive forms until in response to extracellular signals, they become phosphorylated on tyrosine residues, translocate to the nucleus, and bind to specific DNA elements. JAK2, STAT1 and STAT 5 appear to be particularly important in IL-5 mediated eosinophil responses (Mui et al. 1995, Van der Braggen et al. 1995). Despite major advances in this area in recent years, the exact mechanisms by which IL-5 dependent, cell-type specific signals are generated are still to be elucidated.

\section{IL-5, T CELLS AND EOSINOPHILS}

Eosinophils, along with mast cells are the key cells involved in the innate immune response against parasitic infection. The adaptive immune response however is largely dependent on lymphocytes. CD4 +ve T lymphocytes, in particular, are crucial in antigen-driven inflammatory processes and are therefore likely to have an important role in orchestrating specific inflammatory responses. These cells are capable of recognizing foreign antigen that has been processed by antigen presenting cells and can produce pro-inflammatory cytokines in response to such activation which can dramatically amplify the inflammatory response.

One of the major links between $\mathrm{T}$ cells and eosinophils is IL-5. In chronic parasitic disease and in chronic allergic disease, IL-5 is predominantly a $\mathrm{T}$ cell derived cytokine whose major site of action is the eosinophil (Hamid et al. 1991, Mahanty et al. 1993, Ying et al. 1995). Although the development of tissue eosinophilia is T cell dependent, non $\mathrm{T}$ cell derived IL-5 may also play an important role as IL-5 mRNA can also be produced by mast cells and eosinophils (Plaut et al. 1989, Brodie et al. 1992). IL-5, IL-3, and GM-CSF are all capable of stimulating the development of eosinophils from human bone marrow. However, only IL- 
5 was selective for the eosinophil lineage (Clutterbuck et al. 1989). Transgenic mice which constituitively express IL-5 have high level, lifelong eosinophilia (Dent et al. 1990) and the administration of anti-IL-5 neutralising antibody in parasite infected mice totally blocks the production of eosinophilia (Coffman et al. 1989, Egan et al. 1995).

IL-5 is particularly important for the terminal differentiation of committed eosinophil precursors (Clutterbuck et al. 1989, Weller et al. 1992, Ogawa 1994). It activates mature eosinophils and prolongs their survival in culture (Yamaguchi et al. 1988)possibly via its ability to delay apoptosis (Yamaguchi et al. 1991), as well as selectively enhancing eosinophil degranulation, antibody-dependent cytotoxicity and adhesion to vascular endothelium (Lopez et al. 1988, Fujisawa et al. 1990). IL-5 enhances the capacity of eosinophils to release LTC4 (Weller et al. 1992) and also primes basophils, leading to increased histamine and LTC4 generation (Bischoff et al. 1990, Laviollette et al. 1995) and increases synthesis of IgM, IgA, IgE by B cells costimulated with IL-4 (Pene et al. 1988, Purkerson \& Isakson 1992). Although IL-5 on its own is minimally chemoattractant for eosinophils, its ability to significantly enhance the properties of stronger eosinophil chemoattractants such as Rantes and Eotaxin is probably more important (Sanderson, 1992, Sedgwick et al. 1995, Collins et al. 1995, Rothenberg et al. 1996).

\section{IL-5, THE TH2 CYTOKINE PROFILE AND ALLERGIC IN- FLAMMATION}

The production of IL- 5 by T cells, like that of other TH2 cytokines, is independently regulated (Kelso, 1995, Naora et al. 1995, Sewell et al. 1996). Although individual $\mathrm{T}$ cells have the capacity to produce a wide range of cytokines, distinct $\mathrm{T}$ cell populations and cytokine profiles exist in chronic allergic inflammatory diseases (Miyajima et al. 1992, Van Straaten et al. 1994, Kay et al. 1995). There are a number of potential explanations for this phenomenon. Firstly, as has already been mentioned, the IL-4 family of cytokine genes is clustered on chromosome 5, have related evolutionary pathways and are therefore likely to be regulated by similar factors. Secondly, these factors are likely to co-exist in particular microenvironments - particularly when inflammation is driven by similar aetiological agents. And thirdly, these family of cytokines tend to upregulate themselves and downregulate opposing groups of cytokines in an attempt to generate a specific type of adaptive immune response (Modlin et al. 1993, Jung et al. 1995). Indeed, cross-regulation of T helper cell populations occurs and, in the extreme case, this may lead to the development of relatively homogeneous Th1 and Th2 cell T cell population phenotypes (Kelso 1995).

Th2 cell populations tend to produce IL-4, 5, 13 and are associated with humoral immunity and allergy whereas $\mathrm{TH} 1$ cell populations tend to produce IFN- $\gamma$ and IL-2 and are associated with cell mediated immunity (Modlin et al. 1993). IL-4 and IL-13 are the cytokines that predominantly regulate $B$ cell production of IgE and IgE activation of mast cells, both of which have an important role in the allergic immune response. The contribution of IL-4 and IL-5 to allergen induced eosinophil infiltration into the airway has been suggested by experiments showing inhibition of airway eosinophilia in mice with monoclonal antibodies directed against IL-4 and IL-5 (Moser et al. 1992, Kung et al. 1995). These cytokines may act as chemotactic factors for eosinophils, and also promote eosinophil-endothelial adhesion by inducing expression of VCAM-1 on endothelial cells. VCAM -1 in turn may bind to its receptor VLA-4 on the eosinophils leading to the migration of eosinophils to sites of airway inflammation (Elices et al. 1990). However, as has already been mentioned, one of the key roles of IL-5 however is to regulate eosinophil activation, differentiation and survival. Thus, although IL-5 also helps in the activation of B cells (Noelle et al. 1992), its major role is to recruit and activate eosinophils which act in concert with mast cells and IgE producing B cells in the immune response against parasites and in pathophysiology of allergic disease. The relative importance of these pathways is likely to vary according to the specific 'allergic' disease state. Nevertheless, the correlations between detectable levels of IL-5 mRNA in the tissues and IL-5 protein in the serum, eosinophilia development and disease pathology in a wide variety of allergic diseases are striking (including parasite infections, asthma, idiopathic eosinophilia, eosinophilic myalgia and Hodgkins lymphoma) (Sanderson 1992b). Hence, activated $\mathrm{T}$ cells can potentially initiate and propagate allergic inflammation in the airways and participate directly in the events responsible for asthma exacerbation by profoundly influencing both subsequent lymphocyte cell activation and the promotion of growth and differentiation of specific effector leucocytes such as eosinophils.

\section{ASTHMA AND IL-5}

\section{HUMAN STUDIES: IL5 mRNA AND PROTEIN}

Atopic asthma - It has now been well documented that IL-5 is highly expressed in the bronchial mucosa of atopic asthmatics and that the increased IL-5 mRNA present in airway tissues is predominantly $\mathrm{T}$ cell derived although fewer, but 
detectable, numbers of tryptase+ mast cells and EG2+ eosinophils also expressed these transcripts (Hamid et al. 1991, Robinson et al. 1992, Kay et al. 1995, Ying et al. 1995). Immunocytochemical staining of bronchial biopsy sections has confirmed that IL-5 mRNA transcripts are translated into protein in asthmatic subjects (Fukuda et al. 1994).

Increased IL-5 mRNA expression has also been demonstrated in BAL T lymphocytes (Robinson et al. 1992) and in peripheral blood CD4 T cells (Corrigan et al. 1995). The reports of increased IL5 protein levels in the BAL fluid, serum and peripheral blood $\mathrm{T}$ cell supernatants of asthmatics (Walker et al. 1992, 1991, Motojima et al. 1993), support the findings of increased numbers of IL-5 mRNA positive cells in these biological fluids. In addition, $T$ cell lines that have been established from the BAL fluid and peripheral blood of atopic asthmatics secrete increased levels of IL-5 compared to atopic and non-atopic controls, thus providing further evidence that $T$ cells in asthma have a propensity to make both IL-5 mRNA transcripts and IL-5 translated product which can then activate eosinophils (Endo et al. 1993, Okudaira et al. 1995, Till et al. 1995).

Numerous studies have shown that not only is there increased IL-5 mRNA and protein present in asthma, but also that the increased IL-5 is associated with increased eosinophil numbers and increased airways dysfunction (Hamid et al. 1991, Robinson et al. 1993, Sur et al. 1995). It has been demonstrated that the number of IL-5 mRNA-positive cells correlates with the number of eosinophils infiltrating the bronchial mucosa of asthmatic subjects and that IL-5 expression inversely correlates with pulmonary function (Hamid et al. 1991). In addition, the increased expression of IL-5 mRNA in BAL has been directly correlated to asthma symptom severity and inversely correlated to abnormal airway physiology (Robinson et al. 1993). Finally, in the studies where increased IL-5 protein levels were demonstrated in the BAL fluid, serum and peripheral blood $\mathrm{T}$ cell supernatants (Walker et al. 1992, 1991, Motojima et al. 1993) of asthmatic subjects, the IL-5 protein levels detected correlated with the numbers of eosinophils present in these fluids (Walker et al. 1992).

Activated eosinophils have the capacity to produce effector molecules that could participate in the pathogenesis of asthma. The demonstration of eosinophil major basic protein and eosinophil derived neurotoxin indicating degranulation at sites of injury are an important part of the evidence that eosinophils are producing tissue damage in the asthmatic lung (Sur et al. 1995). Hence, the current evidence suggests that the local production of IL-5 in asthmatic airways may play an important role in the priming of eosinophils for subsequent activation, and in enhancing their survival at sites of allergic inflammation (Lopez et al. 1988, Yamaguchi et al. 1988), all of which is likely to be important in asthma.

Intrinsic asthma - Unlike extrinsic asthma, intrinsic asthma usually starts in adulthood, is perennial and is not atopy associated. Nevertheless, an analysis of the inflammatory cell populations present in both BAL fluid and bronchial biopsies from intrinsic asthmatics shows an increase in the number of activated T lymphocytes and eosinophils (Bentley et al. 1992). Indeed, there a large similarities in the inflammatory cells that are present in asthma of diverse aetiology-extrinsic, intrinsic, and occupational (Bentley et al. 1994). Moreover, several studies have now demonstrated increased levels of IL-5 mRNA and protein in the tissue and BAL fluid of intrinsic asthmatics, thereby supporting the role of this cytokine in both intrinsic as well as atopic asthma (Marini et al. 1992, Bentley et al. 1993, Walker et al. 1994, Humbert et al. 1996). These findings support a common $\mathrm{T}$ cell mediated basis for airway inflammation in both forms of asthma.

The difference between intrinsic and atopic asthma is the lack of demonstrable specific IgE to an antigen in individuals with intrinsic disease. Although total serum IgE levels have been noted to be increased in the serum of patients with intrinsic asthma (Burrows et al. 1989) this is not a uniform finding with high positive predictive value (Butcher et al. 1980, Klink et al. 1990). There is evidence that IL- 5 but not IL-4 is increased in the BAL fluid from intrinsic asthmatics (Walker et al. 1994), thus supporting the hypothesis that IL-5 and eosinophilia are key features in both forms of asthma and that differences in the type of cytokine synthesis may undermine the differences in immune pathology that exist between intrinsic and atopic asthma. However, more recent studies examining the expression of high-affinity IgE receptor (Humbert et al. 1996a), and IL-5 and IL-4 mRNA and protein expression in bronchial biopsies from patients with atopic and non-atopic asthma found no difference between atopic and intrinsic asthmatics (Humbert et al. 1996b). Thus, any differences in immune pathology that may exist between intrinsic and atopic asthma may be more subtle than initially expected.

Other allergic pulmonary and non-pulmonary allergic diseases - There is a strong association between IL-5 and eosinophilia in a number of allergic human diseases, including parasitic infections (Coffman et al. 1989, Limaye et al. 1993, Hagan et al. 1996), atopic dermatitis (Frew \& Kay 1988, 
Hamid et al. 1994), eosinopilic myocarditis (Desreumaux et al. 1993), hypereosinopilic syndrome (Schrezenmeier et al. 1993, Satoh et al. 1994) eosinophilic gastroenteritis (Quan et al. 1993, Dubucquoi et al. 1995), allergic rhinitis (Durham et al. 1992), chronic eosinophilic pneumonia (Kita et al. 1996) and other eosinophilic lung diseases (Walker et al. 1994) (Fig. 1).

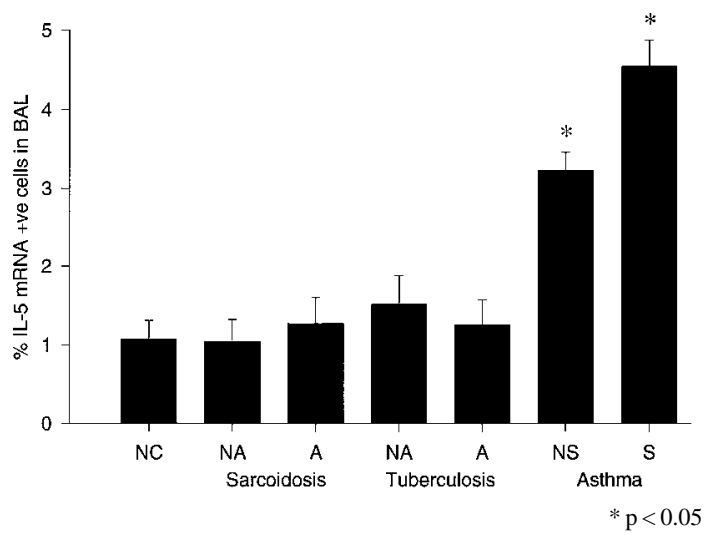

Fig. 1: IL-5 in asthma and other pulmonary diseases. The percentage of IL-5 mRNA + ve cells in the BAL fluid of patients with asthma, sarcoidosis, and tuberculosis. NC: normal controls; NA: non-active disease; A: active disease; NS: nonsymtomatic disease; S: symptomatic disease.

Although there is a strong link between IL-5 and eosinophilia in general, the link between pulmonary eosinophilia and clinical asthma is less direct. Non-eosinophilic inflammatory lung conditions such as tuberculosis and sarcoidosis are not associated with increased IL-5 and eosinophils (Taha et al. 1996, Minshall et al. 1996). However, although eosinophilia is a common feature of asthma many eosinophilic lung diseases are not associated with clinical asthma. This argues that factors other than the presence of eosinophils are also important in the development of clinical asthma. These factors may relate to the level of eosinophil activation, to non-eosinophil dependent parameters that are nevertheless associated with allergic inflammation, or to baseline levels of bronchial hyperresponsivenes. It is therefore likely that the asthma phenotype is most likely to occur when all the relevent factors- including IL5 and eosinophilia, occur together in an individual predisposed to bronchial hyperresponsiveness.

Antigen challenge - The number of activated CD $4+T$ cells and IL-5 mRNA positive cells are increased in asthmatic airways following antigen challenge (Robinson et al. 1993, Bentley et al. 1993) (Fig. 2). Furthermore, CD $4+$ ve T cells have been generally implicated as the major IL-5 mRNA positive cell present following antigen chal- lenge in atopic asthmatics (Bentley et al. 1993, Robinson et al. 1993), although some investigators have reported that the eosinophil is also a source of IL-5 in this setting (Broide et al. 1992). Studies examining BAL samples 18-48 hr after allergen challenge have also shown increased expression of IL-5 (Krishnaswamy et al. 1993, Ohnishi et al. 1993). In addition, IL-5 was a major cytokine product of $\mathrm{T}$ cells from patients with mite associated bronchial asthma when they were stimulated with Dermatophagoides farinae (Kamei et al. 1993).

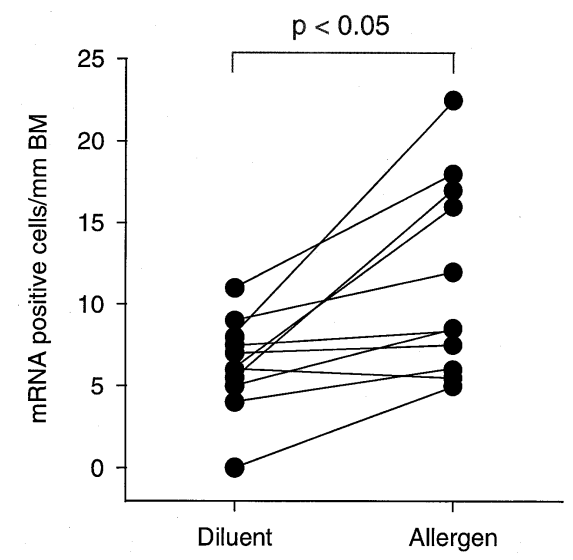

Fig. 2: IL-5 mRNA following allergen challenge humans. The number of IL-5 mRNA +ve cells/mm basement membrane in atopic asthmatic subjects following specific allergen challenge.

The increased IL-5 expression that follows allergen challenge has been demonstrated to inversely correlate with pulmonary function (Bentley et al. 1993) and this adds to the evidence that IL-5 expression and eosinophilia are relevently increased following exposure to antigen in sensitised individuals. Indeed, in the study by Ohnishi et al. (1993) a segmental antigen lung challenge model was used to show that IL-5 was the most important constituent increasing eosinophil survival and that IL-5 correlated with eosinophil recruitment, degranulation and lung injury following inhalation of antigen. These results are in agreement with several other studies that have indicated that increases in the levels of eosinophils and their cationic proteins in the BAL fluid following allergen challenge correlates with the magnitude of the late phase response (Pradalier 1993).

Furthermore, it is well recognized that there is an association between allergic rhinitis and allergic asthma, and hence studies using models of allergen-induced allergic rhinits are therefore relevent to allergic asthma. The results obtained from such models by and large support the above 
findings. For instance, it has been shown that $\mathrm{T}$ cells are the principal source of IL-5 transcripts in the nasal mucosa following allergen induce latephase nasal responses (Ying et al.1993). Similar findings have also been reported in models of allergen induced cutaneous late phase reactions (Kay et al. 1991).

Steroid treatment - The use of anti-inflammatory corticosteroids are the cornerstone of current asthma therapy. They have been shown to be extremely effective clinically. Studies that have examined IL-5 expression in BAL and peripheral blood of asthmatic subjects before and after steroids have shown that the number of IL-5 mRNA positive cells is significantly decreased following oral corticosteroid treatment in steroid-sensitive asthma (Robinson et al. 1993, Corrigan et al. 1995). In contrast, steroid resistant asthma and chronic severe steroid dependent asthma are associated with persistently elevated IL-5 mRNA levels (Leung et al. 1995) and serum IL-5 levels (Alexander et al. 1994), respectively . The decreases in the expression of IL-5 that followed corticosteroid therapy have been associated with decreased eosinophil numbers - especially in the peripheral blood (Corrigan et al. 1995), but increased numbers of IFN- $\gamma$ positive cells in the bronchial mucosa and BAL fluid of asthmatic subjects (Robinson et al. 1993, Leung et al. 1995, Bentley et al. 1996). These findings support the direct link between IL-5 and eosinophils and the inverse relationship between Th1 and Th2 type T cells in asthma (Fig. 3). Hence, corticosteroid treatment in asthma may act by modulation of cytokine expression with consequent inhibition of the local bronchial inflammatory infiltrate and tissue eosinophilia.

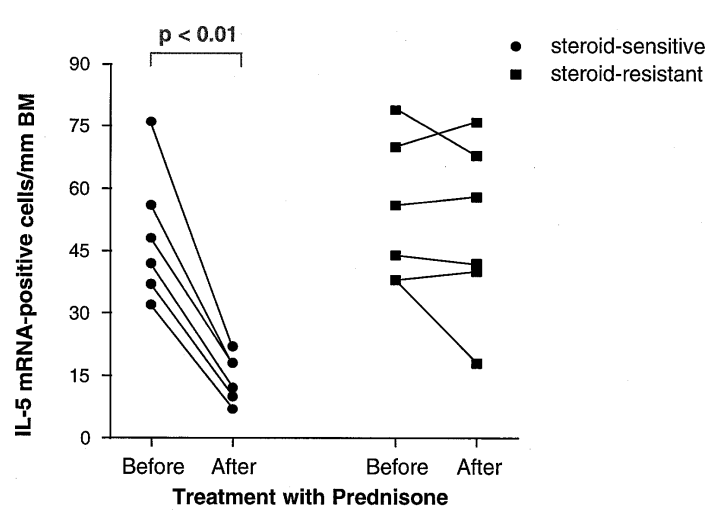

Fig. 3 : prednisone therapy and IL-5 mRNA expression in steroid-sensitive and steroid-resistant asthmatics. The number of IL-5 mRNA +ve cells/mm basement membrane in the bronchial mucosa before and after prednisolone therapy in steroidsensitive and steroid-resistant asthmatics.

\section{IL5 RECEPTOR (Membrane bound and soluble isoforms)}

The link between T cell derived IL-5 and eosinophil activation in asthmatic airways has now been supported by the demonstration that there is an increased number of $\alpha$ IL-5R mRNA positive cells in the bronchial biopsies of atopic and nonatopic asthmatic subjects compared with atopic and non-atopic controls (Fig. 4a, b) and that the eosinophil is the predominant site of this increased $\alpha \mathrm{IL}-$ 5R mRNA expression (Yasruel et al. 1997). We have shown that $93 \%$ of the $\alpha$ IL-5R mRNA positive cells within the bronchial mucosa of asthmatics were also EG2 positive thereby suggesting that IL-5 may play an important local role in stimulating eosinophils via the specific $\alpha$-subunit of its receptor. These results support previous work that has suggested that the lineage specificity of IL-5 is mainly due to the restricted expression of the $\alpha$ subunit of IL5R (Takagi et al. 1995) and demonstrates that the expression of $\alpha$ IL-5R in vivo can be much more cell-restricted than that seen in vitro (Lopez et al. 1991).
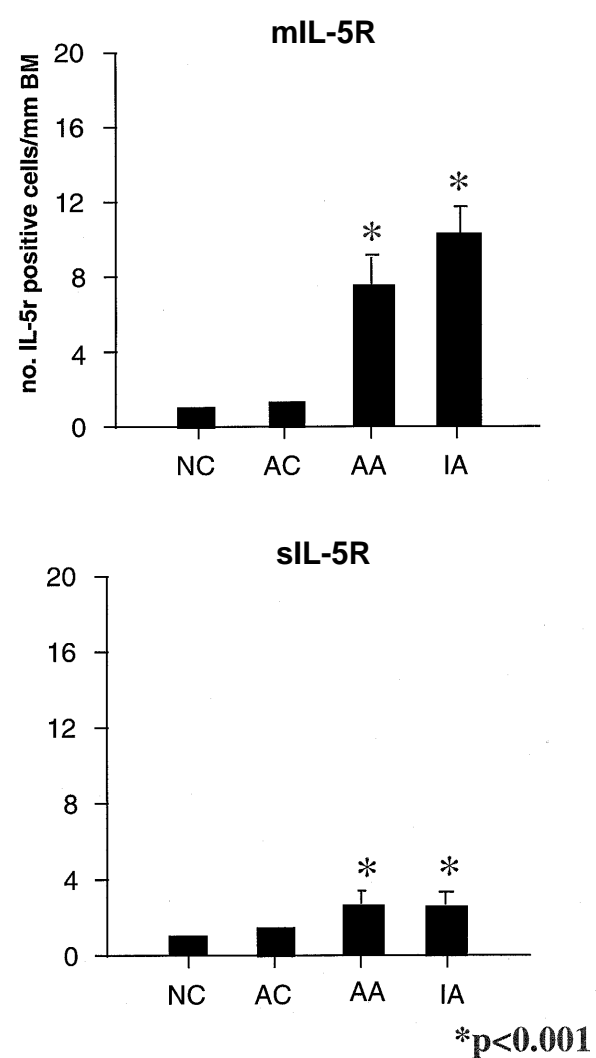

Fig 4 a/b: membrane and soluble IL-5R mRNA expression in asthma. The number of membrane and soluble IL-5 receptor mRNA +ve cells/mm basement membrane in the bronchial mucosa in asthma. mIL-5r: membrane-bound IL-5r isoform; sIL5r: soluble IL-5r isoform; NC: normal controls; AC: atopic controls: AA: atopic asthmatics; IA: intrinsic asthmatics. 
We have also shown that the subset of activated eosinophils that expressed mRNA for membrane bound IL5r inversely correlated with FEV1, whereas the subset of activated eosinophils that expressed mRNA for soluble IL5r directly correlated with FEV1. Hence, not only does this data suggest that the presence of eosinophils expressing IL-5R mRNA contribute towards the pathogenesis of bronchial asthma, but also that the eosinophil phenotype with respect to $\alpha$ IL-5R isoform expression is of central importance. Factors that may modulate the activation phenotype of the airway eosinophils in asthma remain to be clearly determined. The apparent contradiction between an EG2+ eosinophil (EG2 being a marker of activated eosinophils) also expressing $\alpha$ IL-5Rs mRNA and hence representing a downregulated cell can be explained by assuming that EG2 and the aIL5R are associated with different levels of eosinophil activation. Indeed, there is considerable controversy as to the validity of EG2 as a marker of eosinophil activation (Moqbel et al. 1992). Moreover, there is no direct way with which to grade the various potential activation of eosinophils. If EG2 represented a relatively low grade eosinophil activation marker then it is possible that when eosinophils cross the endothelial barrier they all become $\mathrm{EG} 2+$ as a result of influences from the local tissue environment. On the other hand, $\alpha$ IL-5R activation status might represent a higher level of cell activation such that $\alpha \mathrm{IL}-5 \mathrm{Rm}$ positive cells represented a highly activated subset of EG2+ eosinophils and $\alpha$ IL-5Rs positive cells a subset of EG2+ eosinophils that are minimally activated. Hence, although previously published correlations between EG2+ eosinophils and $\mathrm{FEV}_{1}$ were only modest (Hamid et al. 1991), such considerations may explain the strong inverse correlation between $\alpha \mathrm{IL}-5 \mathrm{Rm}$ mRNA positive cells and $\mathrm{FEV}_{1}$ as well as the strong direct correlation between $\alpha$ IL-5Rs mRNA positive cells and $\mathrm{FEV}_{1}$ that was reported.

The central question as to what controls the transcriptional regulation of $\alpha \mathrm{IL}-5 \mathrm{R}$ also remains to be determined. Transforming growth factor B1 has already been shown to downregulate $\alpha$ IL-5R mRNA expression (Zanders 1994), however the effect of single cytokines or combinations of cytokines on the production of different mRNA splice variants of $\alpha \mathrm{IL}-5 \mathrm{R}$ is yet to be elucidated. Nevertheless, the increased number of $\alpha I L-5 R$ mRNA positive eosinophils in the bronchial tissue of asthmatic patients and the differential expression of $\alpha \mathrm{IL}-5 \mathrm{R}$ mRNA isoforms in atopic and nonatopic asthma support the central roles of IL-5 and eosinophils in the pathobiology of asthma.

\section{IL5 ASSOCIATED SIGNAL TX AND GENE ACTIVATION}

It has been shown that cloned human naive CD4 T cells develop into IL-4 and IL-5 producing effector cells as a default pathway (Yang et al. 1995). It could therefore be hypothesised that inert antigenic stimulation of the immune system without concomitant stimulation of cell mediated immune pathways would favour the development of allergic responses. However, how exactly allergen induced activation of TCR and co-stimulatory molecules translates to IL-4 and IL-5 gene activation is not clear. It could also be hypothesised that it would be in the interests of a well coordinated amplification cascade of inflammation to link IL4 and IL-5 gene activation in cytokine producing cells with IL-4 and IL-5 receptor gene activation in target cells. Although we have already quoted some evidence that suggests that this occurs, the exact mechanisms are unclear.

The functions of the alpha subunits of IL-5R and IL-4R have been examined by co-transfecting human cDNAs for these subunits into human cell lines, and it is clear that intracellular signalling is very different in both cases (Chen et al. 1994). How IL-4 mediated intracellular signals interact with the IL-5 gene promoter and whether IL-4 and IL-5 mediated signal transduction can also increase the expression of IL-4 and IL-5 cytokines from source cells and IL-4 and IL-5 receptors in target cells are important issues still to be elucidated. Furthermore, how IL-5 mediated signals translates to an activated eosinophil phenotype is also unclear at present, although recent work has implicated specific GATA binding proteins (Zon et al. 1993). Finally, the response of these cytokine and cytokine receptor genes to therapeutic agents is another important area requiring further study.

\section{ANIMAL STUDIES \\ IL-5 EXPRESSION: SENSITISED AND ANTIGEN CHAL- LENGED ANIMALS}

There are several animal models of allergen induced eosinophilia, late airway responses, and bronchial hyperresponsiveness. These include guinea pigs (Corry et al. 1996), Brown norway (BN) rats (Renzi et al. 1991a,b, 1993, Olivenstein et al. 1993) and mice (Nakajima et al. 1992, Iwamoto et al. 1992). In all these models there is evidence to support a link between IL-5 and airway eosinophila and bronchial hyperresponsiveness. In the $\mathrm{BN}$ rat we have also shown that CD4+ve T cells and Th- 2 cytokines, IL-5 in particular, are involved in allergen induced late airway responses (LAR) (Fig. 5) (Al Assad et al. 1995, Renzi et al. 1996). 


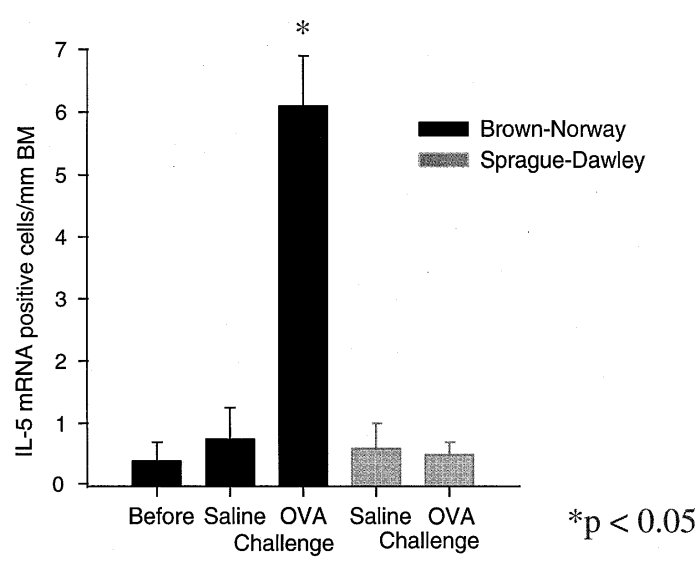

Fig 5: IL-5 mRNA expression following allergen challenge in $\mathrm{BN}$ rats. The number of IL-5 mRNA +ve cells $/ \mathrm{mm}$ basement membrane in the bronchial mucosa of Brown Norway rats and Sprague-Dawley rats following ovalbumin allergen challenge.

We have shown that the airways of OVA sensitized $\mathrm{BN}$ rats are infiltrated predominantly by IL-5 and IL-4 mRNA +ve cells after antigen challenge (Renzi et al. 1996). Eum et al. have demonstrated that eosinophil recruitment into the respiratory epithelium following antigenic challenge is associated with IL-5-dependent bronchial hyperresponsiveness (Eum et al. 1995). Recent work has shown that IL-5 deficiency abolishes eosinophilia, airways hyperreactivity and lung damage in a mouse asthma model and that reconstitution of IL-5 production using recombinant vaccinia virus that expressed IL-5 restored aeroallergen induced eosinophilia and airways dysfunction (Foster et al. 1996). IL-5 transgenic mice show marked eosinophilia and increased reactivity to acetylcholine only after antigen challenge. This suggests that eosinopil activation rather than just large numbers of eosinophils is crucial to the development of BHR (Iwamoto et al. 1995). Interestingly, genetic linkage analysis has linked bronchial hyperesponsiveness in the mouse to murine chromosome 6 - the chromosomal region containing the gene for IL-5 (Ewart et al. 1996).

Using an in vitro lung explant model it has also been shown that airways of OVA sensitized BN rats are infiltrated predominantly by $\mathrm{MBP}+\mathrm{ve}$, IL-5 and IL-4 mRNA +ve cells after ex-vivo antigen challenge (Fig. 6) (Minshall et al. 1996). The demonstration of increased MBP and IL-5 mRNA expression in sensitized lung explants after allergen challenge, suggests that local factors are likely to be very important in the initiation and development of airway eosinophil infiltration.

The most direct demonstration of $\mathrm{T}$ cell involvement in LARs is the finding that these physi-
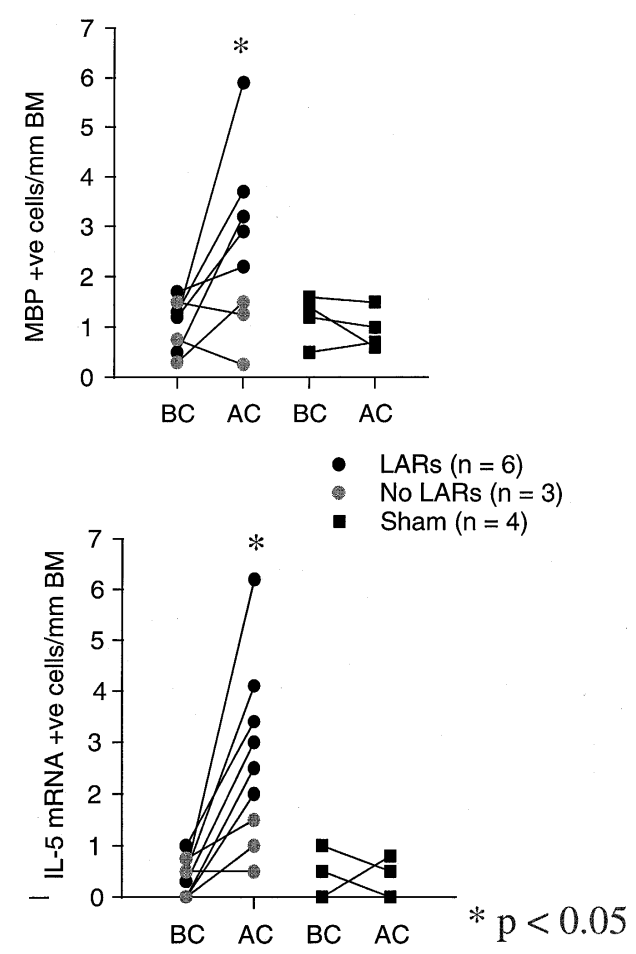

Fig 6: MBP and IL-5 mRNA expression in sensitized BN rat lung explants. The number of MBP and IL-5 mRNA +ve cells/ $\mathrm{mm}$ basement membrane in sensitised Brown Norway rat lung explant tissue before and after ovalbumin allergen challenge. LAR: late phase airway response; $\mathrm{BC}$ : before challenge; $\mathrm{AC}$ : after challenge.

ological responses can be transferred by CD4+ but not CD8+ T cells in rats (Watanabe et al. 1995a,b). To investigate the role of $\mathrm{T}$ cell cytokines in these responses the expression of mRNA for Th2 (IL-4 and IL-5) and Th1(IL -2 and INF- $\gamma$ ) type cytokines in BN rats that were administered aerosolized OVA challenge following the adoptive transfer of either antigen-primed $\mathrm{W} 3 / 25(\mathrm{CD} 4)^{+}$or $\mathrm{OX} 8(\mathrm{CD} 8)^{+} \mathrm{T}$ cells was examined (Fig. 7) (Watanabe et al. 1996). Our results showed that recipients of OVA-primed $\mathrm{CD}^{+} \mathrm{T}$ cells had an increase in the fraction of BAL cells expressing mRNA for IL-4 and IL-5 compared to BSA-primed $\mathrm{CD} 4^{+}$or OVA-primed $\mathrm{CD} 8^{+}$ cells. Recipients of $\mathrm{CD}^{+} \mathrm{T}$ cells had an increase in INF- $\gamma$ mRNA expression after OVA challenge compared to recipients of $\mathrm{BSA}$ primed $\mathrm{CD} 8^{+}$or OVA primed $\mathrm{CD}^{+}{ }^{+} \mathrm{T}$ cells. Hence, $\mathrm{T}$ cell dependent allergen induced late responses are associated with the expression of mRNA for IL-4 and IL-5, indicating Th2 cell activation. Furthermore, the increased expression of INF- $\gamma$ in allergen challenge recipients of antigen-primed $\mathrm{CD} 8^{+} \mathrm{T}$ cells suggests 
that $\mathrm{CD} 8^{+} \mathrm{T}$ cells may be important in modulating allergic responses, thus supporting the conclusions from previous work in this area (Al Assad et al. 1995).

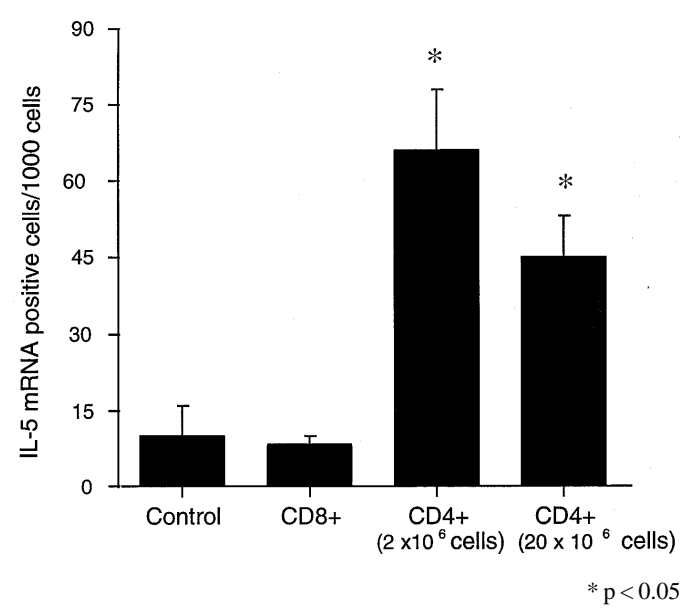

Fig 7: IL-5 mRNA-positive cells in BAL following adoptive transfer of T cells. The number of IL- 5 mRNA + ve cells/1000 cells in the BAL fluid of OVA-challenged BN rats that were recipients of OVA-primed T cells (CD4+ and CD8+groups)

\section{IL-5 AND ANTI-IL-5 ADMINISTRATION}

The importance of IL-5 in animal models of allergen induced bronchial hyperresponsiveness has been further demonstrated by a number of studies which have indicated that IL-5 administration is able to induce late phase responses and BHR and that anti-IL-5 antibody can block allergen induced late phase responses and BHR. IL-5 administration has been shown to increases mucosal exudation, enhance eosinophil recruitment into the lungs and to increases airways responsiveness in models of allergen induced BHR in the guinea pig (Gulbenkian et al. 1992, van Oosterhout et al. 1993a), in mice (van Oosterhout et al. 1993b), and in the Brown Norway rat (Renzi et al. 1996). Moreover, anti-IL-5 administration inhibits eosinophil recruitment and airways hyperresponsiveness in guinea pig models of allergic pulmonary inflammation and allergen induced BHR (Gulbenkian et al. 1992, van Oosterhout et al. 1993a, Das et al. 1995). Similar findings have also been demonstrated in the the mouse (Nagai et al. 1993, Kung et al. 1995) and in the monkey (Mauser et al. 1995).

\section{IL-5 SIGNAL TRANSDUCTION MODULATION}

Many animal studies have now demonstrated that eosinophilia is a uniquely specific phenomenon regulated by IL- 5 which of course suggest that IL-5 gene expression is under specific control. This control has been investigated by exam- ining the roles of various transcription factors in animal T cell lines (Lee et al. 1994, Karlen et al. 1996). These studies have implicated AP-1, NFAT like factors and GATA binding proteins although it is still not clear how all these molecules are related in controlling IL-5 promoter activity (Lee et al. 1994, Yamagata et al. 1995, Karlen et al. 1996).

\section{THERAPEUTIC IMPLICATIONS}

Asthma is a complex disorder involving a specific inflammatory response in the airways that is largely co-ordinated by activated $\mathrm{T}$ cells and involves various other inflammatory effector cells especially eosinophils but also B cells and mast cells, as well as functional and structural changes in the resident airway tissue cells. The central role of activated lymphocytes and eosinophils in asthma would argue for the likely therapeutic success of strategies to block T cell and eosinophil activation. It is likely that at least some of the success of steroids in suppressing asthmatic inflammation is due to their ability to suppress T lymphocyte and eosinophil activation. However, steroids have a wide range of effects on many other inflammatory and non-inflammatory cells. Although this may be the basis of the therapeutic usefulness of steroids, it is also the basis of the significant side effects associated with their long term use. Importantly, more targeted therapies may avoid the complications associated with steroids. Such therapies could target key $\mathrm{T}$ cell activation proteins and cytokines by various means including blocking antibodies (eg anti-CD4, anti-CD40, anti-IL-5 etc), antisense oligonucleotides to their specific mRNAs, and/or selective inhibition of the promoter sites for these genes. Another option would be to target key eosinophil activation mechanisms including the $\alpha$ IL5r. As always, the risk to benefit ratio of such strategies await the results of well conducted clinical trials.

The groundwork for such strategies is currently being laid. Anti-IL5 antibodies have been shown to inhibit pulmonary eosinophilia, tissue damage and hypereactivity in allergic animal models (Egan et al. 1995, Hagan et al. 1996). It has also been demonstrated that FK506 could suppress IL-5 production and gene expression in a dose dependent manner-(Okudaira et al. 1995). In addition, the data of Yasruel et al. (1996) linking soluble $\alpha$ IL-5r expression with improved $\mathrm{FEV}_{1}$ levels and studies examining the therapeutic potential of soluble $\alpha \mathrm{IL}$ $5 r$ suggest that they may offer particular promise (Devos et al. 1995). Indeed, the possibility of the antagonistic properties of the $\alpha$ IL-5Rs being used as a therapeutic option in eosinophil mediated disease states such as asthma and allergic rhinitis is 
already being investigated (Zanders 1994, Devos et al. 1995), although the response of $\alpha$ IL-5R expression to antigen challenge and steroid treatment are still important areas of further study. Interestingly, the potential biological modulatory role of $\alpha \mathrm{IL}-5 \mathrm{Rs}$ also has important implications for the development of IL-5R antagonists as these antagonists may not differentiate between binding to and inhibiting $\alpha \mathrm{IL}-5 \mathrm{Rm}$, and binding to and inhibiting $\alpha$ IL-5Rs (Devos et al. 1994, 1995). Furthermore, in a murine model of allergic responses, it has been shown that soluble $\alpha \mathrm{IL}-5 \mathrm{r}$ suppressed antigen induced BAL eosinophilia with little effect on airway hyperreactivity reminding us again of the complexities involved in all these responses (Yamaguchi et al. 1994).

\section{CONCLUSIONS}

In summary, activated T lymphocytes, the production of IL-5 and eosinophil activation are particularly important in the asthmatic response. $\mathrm{Hu}-$ man studies in asthma and studies in allergic animal models have clearly emphasised the unique role of IL-5 in linking adaptive immunity and T lymphocytes with the eosinophil effector cell. However, how this link between IL-5 producing $\mathrm{T}$ cells and IL-5 target eosinophils is initiated, propagated and attenuated is still an area that requires further research. In addition, what the exact activation characteristics of the $\mathrm{T}$ lymphocytes in asthma are $(\mathrm{V} \beta$ restriction of their TCR in response to specific antigens) and what the relative effects of T cells and Th2 cytokines are on all effector inflammatory cells and on structural cells (epithelium, fibroblasts and smooth muscle cells) of asthmatic airways are also important issues that need to be resolved. It is hoped that answers to these questions in the near future will provide us with an increased understanding of asthma pathogenesis, and ultimately lead to novel, highly targeted and effective therapeutic strategies for asthma management.

\section{REFERENCES}

Al Assad AS, Yang JP, Hamid Q, Yasruel Z, Renzi PM 1995. Semi-quantitative analysis of cytokine mRNA in rat lungs after challenge. Am J Resp Crit Care Med 151.4: (A392).

Alexander AG, Barkans J, Moqbel R, Barnes NC, Kay AB, Corrigan CJ 1994. Serum interleukin 5 concentrations in atopic and non-atopic patients with glucocorticoid-dependent chronic severe asthma. Tho$\operatorname{rax}$ 49: 1231-1233.

Azuma C, Tanabe T, Konishi M, Kinashi T, Noma T, Matsuda F, Yaoita Y, Takatsu K, Hammarstrom L, Smith CI 1986. Cloning of cDNA for human T-cell replacing factor (interleukin-5) and comparison with the murine homologue. Nucleic Acids Research 14:
9149-9158.

Azzawi M, Bradley B, Jeffery PK, Frew AJ, Wardlaw AJ, Assoufi B, Collins JV, Durham SR, Knowles GK, Kay AB 1990. Identification of activated T lymphocytes and eosinophils in bronchial biopsies in stable atopic asthma. Am Rev Respir Dis 142: 14071413.

Bentley AM, Menz G, Storz C, Robinson DS, Bradley B, Jeffery PK, Durham SR, Kay AB 1992. Identification of T lymphocytes, macrophages and activated eosinophils in the bronchial mucosa in intrinsic asthma: relationship to symptoms and bronchial responsiveness. Am Rev Respir Dis 146: 500-506.

Bentley AM, Hamid Q, Robinson DS, Schotman E, Meng Q, Assoufi B, Kay AB, Durham SR 1996. Prednisolone treatment in asthma. Reduction in the numbers of eosinophils, T cells, tryptase-only positive mast cells, and modulation of IL-4, IL-5, and interferon-gamma cytokine gene expression within the bronchial mucosa. Am J Resp Crit Care Med 153: 551-556.

Bentley AM, Durham SR, Kay AB 1994. Comparison of the immunopathology of extrinsic, intrinsic and occupational asthma. $J$ Investig Allergy \& Clin Immunol 4: 222-232.

Bentley AM, Meng Q, Robinson DS, Hamid Q, Kay AB, Durham SR 1993. Increases in activated Tymphocytes, eosinophils, and cytokine mRNA expression for Interleukin-5 and granulocyte/macrophage colony-stimulating factor in bronchial biopsies after allergen challenge in atopic asthmatics. Am J Resp Cell Mol Biol 8: 35-42.

Bischoff SC, Brunner T, De Weck AL, Dahinden CA 1990. Interleukin 5 modifies histamine release and leukotriene generation by human basophils in response to diverse agonists. J Exp Med 172: 1577 1582 .

Bradley BL, Azzawi M, Jacobson M, Assoufi B, Collins JV, Irani A-MA, Schwartz LB, Durham SR, Jeffery PK, Kay AB 1991. Eosinophils, T-lymphocytes, mast cells, neutrophils, and macrophages in bronchial biopsy specimens from atopic asthma: comparison with biopsy specimens from atopic subjects without asthma and normal control subjecs and relationship to bronchial hyperresponsiveness. $\mathrm{J} \mathrm{Al}$ lergy Clin Immunol 88: 661-674.

Bazan JF 1990. Structural design and molecular evolution of a cytokine receptor superfamily. Proc Natl Acad Sci USA 87: 6934-6938.

Boulay JL, Paul WE 1992. The interleukin-4-related lymphokines and their binding to hematopoietin receptors. J Biol Chem 267: 20525-20528.

Boulay JL, Paul WE 1992. The interleukin-4 family of lymphokines. Curr Opin Immunol 4: 294-298.

Bousquet J, Chanez P, Lacoste JY, Barneon G, Ghavanian N, Enander I, Venge P, Ahlstedt S, Simony-Lafontaine J, Godard P 1990. Eosinophilic inflammation in asthma. New Engl J Med 323: 10331039.

Broide DH, Paine MM, Firestein GS 1992. Eosinophils express interleukin 5 and granulocyte macrophagecolony-stimulating factor mRNA at sites of allergic 
inflammation in asthmatics. J Clin Invest 90: 14141424.

Burrows B, Martinez FD, Halonen M, Barbee RA, Cline MG 1989. Association of asthma with serum IgE levels and skin-test reactivity to allergens. New Engl J Med 320: 271-277.

Butcher BT, O’Neil CE, Reed MA, Salvaggio JE 1980. Radioallergosorbent testing of toluene diisocyanatereactive individuals using $\mathrm{p}$-tolyl isocyanate antigen. J Allergy \& Clin Immunol 66: 213-216.

Chen JX, Watanabe S, Muto A, Miyajima A, Yokota T, Arai K 1994. Activation of early response genes and cell proliferation by human interleukin-3, granulocyte-macrophage colony-stimulating factor, and interleukin-5 receptors: comparison with human interleukin-4 receptor signaling. J Allergy \& Clin Immunol 94: 605-611

Clutterbuck EJ, Hirst EM, Sanderson CJ 1989. Human interleukin-5 (IL-5) regulates the production of eosinophils in human bone marrow cultures: comparison and interaction with IL-1, IL-3, IL-6, and GMCSF. Blood 73: 1504-1512.

Coffman RL, Seymour BW, Hudak S, Jackson J, Rennick D 1989. Antibody to interleukin-5 inhibits helminth-induced eosinophilia in mice. Science 245: 308-310.

Collins PD, Marleau S, Griffiths-Johnson DA, Jose PJ, Williams TJ 1995. Cooperation between interleukin5 and the chemokine eotaxin to induce eosinophil accumulation in vivo. J Exp Med 182: 1169-1174.

Cornelis S, Fache I, Van der Heyden J, Guisez Y, Tavernier J, Devos R, Fiers W, Plaetinck G 1995. Characterization of critical residues in the cytoplasmic domain of the human interleukin-5 receptor alpha chain required for growth signal transduction. Eur J Immunol 25: 1857-1864.

Corrigan, CJ, Hamid Q, North J, Barkans J, Moqbel R, Durham S, Gemou-Engesaeth V, Kay AB 1995. Peripheral blood CD4 but not CD8 T-lymphocyte in patients with exacerbation of asthma transcribe and translate messenger RNA encoding cytokines which prolong eosinophil survival in the context of a Th-2 type pattern: Effect of glucocorticoid therapy. $A m$ J Respir Cell Mol Biol 12: 567-578.

Corry DB, Folkesson HG, Warnock ML, Erle DJ, Matthay MA, Wiener-Kronish JP, Locksley RM 1996. Interleukin 4, but not interleukin 5 or eosinophils, is required in a murine model of acute airway hyperreactivity. J Exp Med 183: 109-117.

Das AM, Williams TJ, Lobb R, Nourshargh S 1995. Lung eosinophilia is dependent on IL-5 and the adhesion molecules CD18 and VLA-4, in a guinea-pig model. Immunology 84: 41-46.

Denburg JA, Silver JE, Abrams JS 1991.Interleukin-5 is a human basophilopoietin: induction of histamine content and basophilic differentiation of HL-60 cells and of peripheral blood basophil-eosinophil progenitors. Blood 77: 1462-1468.

Dent LA, Strath M, Mellor AL, Sanderson CJ 1990. Eosinophilia in transgenic mice expressing interleukin 5. J Exp Med 172: 1425-1431.

Desreumaux P, Janin A, Dubucquoi S, Copin MC,
Torpier G, Capron A, Capron M, Prin L 1993. Synthesis of interleukin-5 by activated eosinophils in patients with eosinophilic heart diseases. Blood 82 : 1553-1560.

Devos R, Plaetinck G, Cornelis S, Guisez Y, Van der Heyden J, Tavernier J 1995. Interleukin-5 and its receptor: a drug target for eosinophilia associated with chronic allergic disease. J Leuk Biol 57: 813819.

Devos R, Guisez Y, Plaetinck G, Cornelis S, Tavernier J, Van der Heyden J, Foley LH, Scheffler JE 1994. Covalent modification of the interleukin-5 receptor isothiazolones leads to inhibition of binding of interleukin-5. Eur J Bioch 225: 635-640.

Devos R, Guisez Y, Cornelis S, Verhee A, Van der Heyden J, Manneberg M, Lahm H-W, Fiers W, Tavernier J, Plaetnick G 1993. Recombinant soluble human interleukin-5 (hIL-5) receptor molecules: cross-linking and stoichiometry of binding to IL-5. J Biol Chem 268: 6581-6587.

Dubucquoi S, Janin A, Klein O, Desreumaux P, Quandalle P, Cortot A, Capron M, Colombel JF 1995. Activated eosinophils and interleukin 5 expression in early recurrence of Crohn's disease. Gut 37: 242-246.

Dunnill MS 1960. The pathology of asthma, with special reference to changes in the bronchial mucosa. J Clin Pathol 13: 27-33.

Durham SR, Ying S, Varney VA, Jacobson MR, Sudderick RM, Mackay IS, Kay AB, Hamid QA 1992. Cytokine messenger RNA expression for IL3, IL-4, IL-5, and granulocyte/macrophage-colonystimulating factor in the nasal mucosa after local allergen provocation: relationship to tissue eosinophilia. J Immunol 148: 2390-2394.

Egan RW, Athwahl D, Chou CC, Emtage S, Jehn CH, Kung TT, Mauser PJ, Murgolo N, Bodmer MW 1995. Inhibition of pulmonary eosinophilia and hyperreactivity by antibodies to interleukin-5. Intern Arch Allergy \& Immunol 107: 321-322.

Eidelman, DH, Minshall E, Dandurand RJ, Schotman E, Song YL, Yasruel Z, Moqbel R, Hamid Q 1996. Evidence for major basic protein immunoreactivity and IL-5 gene activation during the late phase response in explanted airways. Am J Respir Cell Mol Biol 15: 582-589.

Elices, MJ, Osborn L, Takadu Y, Crouse C, Luhowskyj S, Hemler ME, Lobb RR 1990. VCAM-1 on activated endothelium interacts with the leucocyte integrin VLA-4 at a site distinct from the VLA-4/ fibronectin binding site. Cell 60: 577-584.

Endo H, Iwamoto I, Nakajima H, Yoshida S 1993. In vitro interleukin-5 production of peripheral blood mononuclear cells is increased in patients with asthma. Intern Arch Allergy \& Immunol 101: 425430.

Eum SY, Haile S, Lefort J, Huerre M, Vargaftig BB 1995. Eosinophil recruitment into the respiratory epithelium following antigenic challenge in hyper- $\mathrm{IgE}$ mice is accompanied by interleukin 5-dependent bronchial hyperresponsiveness. Proc Nat Acad Sci Unit Stat Am 92: 12290-12294. 
Ewart SL, Mitzner W, DiSilvestre DA, Meyers DA, Levitt RC 1996. Airway hyperresponsiveness to acetylcholine: segregation analysis and evidence for linkage to murine chromosome 6. Am J Resp Cell \& Mol Biol 14: 487-495.

Frew AJ, Kay AB 1988. The relationship between infiltrating CD4+ lymphocytes, activated eosinophils, and the magnitude of the allergen-induced late phase cutaneous reaction in man. J Immunol 141: 41584164.

Fujisawa T, Abu-Ghazaleh R, Kita H, Sanderson CJ, Gleich GJ 1990. Regulatory effect of cytokines on eosinophil degranulation. J Immunol 144: 642-646.

Fukuda T, Nakajima H, Fukushima Y, Akutsu I, Numao T, Majima K, Motojima S, Sato Y, Takatsu K, Makino Syeau Detection of interleukin-5 messenger RNA and interleukin-5 protein in bronchial biopsies from asthma by nonradioactive in situ hybridization and immunohistochemistry. J Allergy \& Clin Immunol 94: 584-593.

Foster PS, Hogan SP, Ramsay AJ, Matthaei KI, Young IG 1996. Interleukin 5 deficiency abolishes eosinophilia, airways hyperreactivity, and lung damage in a mouse asthma model. J Exp Med 183: 195-201.

Gulbenkian AR, Egan RW, Fernandez X, Jones H, Kreutner W, Kung T, Payvandi F, Sullivan L, Zurcher JA, Watnick AS 1992. Interleukin-5 modulates eosinophil accumulation in allergic guinea pig lung. Am Rev Resp Dis 146: 263-266.

Hagan JB, Bartemes KR, Kita H, Ottesen EA, Awadzi K, Nutman TB, Gleich GJ 1996. Elevations in granulocyte-macrophage colony-stimulating factor and interleukin-5 levels precede posttreatment eosinophilia in onchocerciasis. J Infect Dis 173: 12771280.

Hamid Q, Boguniewicz M, Leung DY 1994. Differential in situ cytokine gene expression in acute versus chronic atopic dermatitis. J Clin Invest 94: 870876.

Hamid Q, Song YL, Minshall E, Bai TR, Hegele RG, Hogg JC 1996. Small airways inflammation in asthma. Am J Resp Crit Care Med 153.4: (A878).

Hamid Q, Azzawi M, Sun Ying, Moqbel R, Wardlaw AJ, Corrigan CJ, Bradley B, Durham SR, Collins JV, Jeffery PK, Quint DJ, Kay AB 1991. Expression of mRNA for interleukin-5 in mucosal bronchial biopsies from asthma. J Clin Invest 87 : 1541-1546.

Humbert M 1996. Airways inflammation in asthma and chronic bronchitis. Clin \& Exp Allergy 26: 735-737.

Humbert M, Grant JA, Tabordabarata L, Durham SR, Pfister R, Menz G, Barkans J, Ying S, Kay AB 1996. High-affinity Ige receptor (Fc-epsilon-ri)-bearing cells in bronchial biopsies from atopic and nonatopic asthma. Am J Resp \& Crit Care Med 153: 1931-1937.

Humbert M. Durham SR, Ying S, Kimmitt P, Barkans J, Assoufi B, Pfister R, Menz G, Robinson DS, Kay AB, Corrigan CJ 1996. IL-4 and IL-5 mRNA and protein in bronchial biopsies from patients with atopic and nonatopic asthma: Evidence against asthma being a distint immunopathological entity.
Am J Resp \& Crit Care Med 154: 1497-1504.

Ihle JN 1995. Cytokine receptor signalling. Nature 377: 591-594.

Ihle JN, Witthuhn BA, Quelle FW, Yamamoto K, Silvennoinen O 1995. Signaling through the hematopoietic cytokine receptors. Ann Rev Immunol 13: 369-398.

Iwamoto I, Tomoe S, Tomioka H, Takatsu K, Yoshida S 1992. Role of CD4+ T lymphocytes and interleukin5 in antigen-induced eosinophil recruitment into the site of cutaneous late-phase reaction in mice. J Leuk Biol 52: 572-578.

Iwamoto T, Takatsu K 1995. Evaluation of airway hyperreactivity in interleukin-5 transgenic mice. Intern Arch Allergy \& Immunol 108 Suppl 1: 28-30.

Jeffery PK, Wardlaw AJ, Nelson FC, Collins JV, Kay AB 1989. Bronchial biopsies in asthma. An ultrastructural, quantitative study and correlation with hyperreactivity. Am Rev Respir Dis 140: 1745-1753.

Jung T, Schauer U, Rieger C, Wagner K, Einsle K, Neumann C, Heusser C 1995. Interleukin-4 and interleukin-5 are rarely co-expressed by human $\mathrm{T}$ cells. Eur J Immunol 25: 2413-2416.

Kamei T, Ozaki T, Kawaji K, Banno K, Sano T, Azuma M, Ogura T 1993. Production of interleukin-5 and granulocyte/macrophage colony-stimulating factor by $T$ cells of patients with bronchial asthma in response to Dermatophagoides farinae and its relation to eosinophil colony-stimulating factor. Am J Resp Cell \& Mol Biol 9: 378-385.

Karlen S, Dercole M, Sanderson CJ 1996. Two pathways can activate the interleukin-5 gene and induce binding to the conserved lymphokine element. Blood 88: 211-221.

Kay AB, Ying S, Durham SR 1995. Phenotype of cells positive for interleukin-4 and interleukin-5 mRNA in allergic tissue reactions. Intern Arch Allergy \& Immunol 107: 208-210.

Kay AB, Ying S, Durham SR 1995. Phenotype of cells positive for interleukin-4 and interleukin-5 mRNA in allergic tissue reactions. Intern Arch Allergy \& Immunol 107: 208-210.

Kay AB, Ying S, Varney V, Gaga M, Durham SR, Moqbel R, Wardlaw AJ, Hamid Q 1991. Messenger RNA expression of the cytokine gene cluster, interleukin 3 (IL-3), IL-4, IL-5, and granulocyte/ macrophage colony-stimulating factor, in allergeninduced late-phase cutaneous reactions in atopic subjects. J Exp Med 173: 775-778.

Kelso A 1995. Th1 and Th2 subsets:paradigms lost? Immunology today 16.8: 374-379.

Kita H, Sur S, Hunt LW, Edell ES, Weiler DA, Swanson MC, Samsel RW, Abrams JS, Gleich GJ 1996. Cytokine production at the site of disease in chronic eosinophilic pneumonitis. Am J Resp \& Crit Care Med 153: 1437-1441.

Klink M, Cline MG, Halonen M, Burrows B 1990. Problems in defining normal limits for serum IgE. $J$ Allergy \& Clin Immunol 85: 440-444.

Koike M, Takatsu K 1994. IL-5 and its receptor: which role do they play in the immune response. Int Arch Allergy Immunol 104: 1-9. 
Kosugi H, Nakagawa Y, Hotta T, Saito H, Miyajima A, Arai K, Yokota T 1995. Structure of the gene encoding the alpha subunit of the human interleukin 3 receptor. Bioch \& Biophys Res Comm 208: 360367.

Krishnaswamy G, Liu MC, Su SN, Kumai M, Xiao HQ, Marsh DG, Huang SK 1993. Analysis of cytokine transcripts in the bronchoalveolar lavage cells of patients with asthma. Am J Resp Cell \& Mol Biol 9: 279-286.

Kung, TT, Stelts DM, Zurcher JA, Adams III GK, Egan RW, Kreutner W, Watnick AS, Jones H, Chapman RW 1995. Involvement of IL-5 in a murine model of allergic pulmonary inflammation: Prophylactic and therapeutic effect of an anti-IL-5 antibody. Am J Resp Cell Mol Biol 13: 360-365.

Kuwano K, Bosken CH, Paré PD, Bai TR, Wiggs BR, Hogg JC 1993. Small airways dimensions in asthma and in chronic obstructive pulmonary disease. $A m$ Rev Respir Dis 148: 1220-1225.

Laitinen LA, Laitinen A, Haahtela T. 1993. Airway mucosal inflammation even in patients with newly diagnosed asthma. Am Rev Respir Dis 147: 697-704.

Laviolette M, Ferland C, Comtois JF, Champagne K, Bosse M, Boulet LP 1995. Blood eosinophil leukotriene $\mathrm{C} 4$ production in asthma of different severities. Eur Resp Journal 8: 1465-1472.

Lee HJ, Matsuda I, Naito Y, Yokota T, Arai N, Arai K 1994. Signals and nuclear factors that regulate the expression of interleukin-4 and interleukin-5 genes in helper T cells. J Allergy \& Clin Immunol 94: 594604.

Leung DM, Martin RJ, Szefler SJ, Sher ER, Ying S, Kay AB, Hamid Q 1995. Dysregulation of Interleukin-4, Interleukin-5, and Interferon-g gene expression in steroid resistant asthma. $J$ Exp Med 181: 33-40.

Limaye AP, Ottesen EA, Kumaraswami V, Abrams JS, Regunathan J, Vijayasekaran V, Jayaraman K, Nutman TB 1993. Kinetics of serum and cellular interleukin-5 in posttreatment eosinophilia of patients with lymphatic filariasis. J Infect Dis 167: 13961400.

Lopez AF, Vadas MA, Woodcock JM, Milton SE, Lewis A, Elliott MJ, Gillis D, Ireland R, Olwell E, Park LS 1991. Interleukin-5, interleukin-3, and granulocytemacrophage colony stimulating factor cross-compete for binding to cell surface receptors on human eosinophils. J Biol Chem 266: 24741-24747.

Lopez AF, Sanderson CJ, Gamble JR, Campbell HR, Young IG, Davas MA 1988. Recombinant human interleukin-5 is a selective activator of human eosinophil function. J Exp Med 167: 219-224.

Macklem PT, Proctor DF, Hogg JC 1970. The stability of peripheral airways. Resp Physiol 8: 191-203.

Mahanty S, Nutman TB 1993. The biology of interleukin-5 and its receptor. Cancer Investigation 11: 624-634.

Marini M, Avoni E, Hollemborg J, Mattoli S 1992. Cytokine mRNA profile and cell activation in bronchoalveolar lavage fluid from nonatopic patients with symptomatic asthma. Chest 102: 661-669.
Mauser PJ, Pitman AM, Fernandez X, Foran SK, Adams GK 3rd, Kreutner W, Egan RW, Chapman RW 1995. Effects of an antibody to interleukin-5 in a monkey model of asthma. Am J Resp \& Crit Care Med 152: 467-472.

McFadden ER Jr, Gilbert IA 1992. Asthma. New Engl J Med 327: 1928-1937.

Milburn MV, Hassell AM, Lambert MH, Jordan SR, Proudfoot AE, Graber P, Wells TN 1993. A novel dimer configuration revealed by the crystal structure at $2.4 \mathrm{~A}$ resolution of human interleukin-5. $\mathrm{Na}$ ture 363: 172-176.

Migita M, Yamaguchi N, Mita S, Higuchi S, Hitoshi Y, Yoshida Y, Tomonaga M, Matsuda I, Tominaga A, Takatsu K 1991. Characterization of the human IL5 receptors on eosinophils. Cellular Immunology 133: 484-497.

Minshall E, Tsicopoulos A, Yasruel Z, Bernard A, Wallaert B, Vorng H, Tonnel A, Hamid Q 1996. High expression of cytoline gene transcripts in active pulmonary sarcoidosis compared to non-active pulmonary sarcodoisis and normal controls. Am J Respir Crit Care Med 153: A868.

Miyajima A, Kitamura T, Harada N, Yokota T, Arai K 1992. Cytokine receptors and signal transduction. Ann Rev Immunol 10: 295-331.

Matsumoto K, Schleimer RP, Saito H, Iikura Y, Bochner BS 1995. Induction of apoptosis in human eosinophils by anti-Fas antibody treatment in vitro. Blood 86: 1437-1443.

Miyajima A, Mui AL, Ogorochi T, Sakamaki K 1993. Receptors for granulocyte-macrophage colonystimulating factor, interleukin-3, and interleukin-5. Blood 82: 1960-1974.

Miyajima A, Mui AL, Ogorochi T, Sakamaki K 1993. Receptors for granulocyte-macrophage colonystimulating factor, interleukin-3, and interleukin-5. Blood 82: 1960-1974.

Modlin RL, Nutman TB 1993. Type 2 cytokines and negative immune regulation in human infections. Curr Opin Immunol 5: 511-517.

Moqbel R, Barkans J, Bradley BL, Durham SR, Kay AB 1992. Application of monoclonal antibodies against major basic protein (BMK-13) and eosinophil cationic protein (EG1 and EG2) for quantifying eosinophils in brochial biopsies from atopic asthma. Clin Exp Allergy 22: 265-273.

Moser R, Fehr J, Bruijnzeel PLB 1992. IL-4 controls the selective endothelium driven transmigration of eosinophils from allergic individuals. J Immunol 149: 1432-1438.

Motojima S, Akutsu I, Fukuda T, Makino S, Takatsu K 1993. Clinical significance of measuring levels of sputum and serum ECP and serum IL-5 in bronchial asthma. Allergy 48 (17 Suppl): 98-106.

Mui AL, Wakao H, Harada N, O'Farrell AM, Miyajima A 1995. Interleukin-3, granulocyte-macrophage colony-stimulating factor, and interleukin-5 transduce signals through two forms of STAT5. J Leuk Biol 57: 799-803.

Murata, Y, Takaki S, Migita S, Kikuchi Y, Tominaga A, Takatsu K 1992. Molecular cloning and expression 
of the human interleukin-5 receptor. J Exp Med 175: 341-351.

Nagai H, Yamaguchi S, Inagaki N, Tsuruoka N, Hitoshi Y, Takatsu K 1993. Effect of anti-IL-5 monoclonal antibody on allergic bronchial eosinophilia and airway hyperresponsiveness in mice. Life Sciences. 53: Pl 243-247.

Nakajima H, Iwamoto I, Tomoe S, Matsumura R, Tomioka H, Takatsu K, Yoshida S 1992. CD4+ Tlymphocytes and interleukin-5 mediate antigen-induced eosinophil infiltration into the mouse trachea. Am Rev Respir Dis 146: 374-377.

Naora H, Young IG 1995. Comparison of the mechanisms regulating IL-5, IL-4, and three other lymphokine genes in the Th2 clone D10.G4.1. Exp Hematol 23: 597-602.

Nicola NA 1989. Hemopoietic cell growth factors and their receptors. Ann Rev Biochem 58: 45-77.

Noelle R, Snow EC 1992. T helper cells. Curr Opin Immunol 4: 333-337.

Ogawa M 1994. Hematopoiesis. J Allergy \& Clin Immunol 94: 645-650.

Ohnishi T, Sur S, Collins DS, Fish JE, Gleich GJ, Peters SP 1993. Eosinophil survival activity identified as interleukin-5 is associated with eosinophil recruitment and degranulation and lung injury twenty-four hours after segmental antigen lung challenge. $J \mathrm{Al}$ lergy \& Clin Immunol 92: 607-615.

Okudaira H, Mori A, Suko M, Etoh T, Nakagawa H, Ito K 1995. Enhanced production and gene expression of interleukin-5 in patients with bronchial asthma: possible management of atopic diseases by downregulation of interleukin-5 gene transcription. Internat Arch Allergy \& Immunol 107: 255-258.

Olivenstein R, Renzi PM, Yang JP, Rossi P, Laberge S, Waserman S, Martin JG 1993. Depletion of OX-8 lymphocytes from the blood and airways using monoclonal antibodies enhances the late airway response in rats. J Clin Invest 92: 1477-1482.

Pazdrak K, Schreiber D, Forsythe P, Justement L, Alam R 1995. The intracellular signal transduction mechanism of interleukin 5 in eosinophils: the involvement of lyn tyrosine kinase and the Ras-Raf-1-MEK-microtubule-associated protein kinase pathway. $J$ Exp Med 181: 1827-1834.

Pene J, Rousset F, Briere F, Chretien I, Wideman J, Bonnefoy JY, De Vries JE 1988. Interleukin 5 enhances interleukin 4-induced IgE production by normal human B cells. The role of soluble CD23 antigen. Eur J Immunol 18: 929-935.

Plaut M, Pierce JH, Watson CJ, Hanley-Hyde J, Nordan RP, Paul WE 1989. Mast cell lines produce lymphokines in response to cross-linkage of Fc epsilon RI or to calcium ionophores. Nature 339: 64-67.

Pradalier A 1993. Late-phase reaction in asthma: basic mechanisms. Internat Arch Allergy \& Immunol 101: 322-325.

Purkerson JM, Isakson PC 1992. Interleukin 5 (IL-5) provides a signal that is required in addition to IL4 for isotype switching to immunoglobulin (Ig) G1 and IgE. J Exp Med 175: 973-982.

Quan SF, Sedgwick JB, Nelson MV, Busse WW 1993.
Corticosteroid resistance in eosinophilic gastritisrelation to in vitro eosinophil survival and interleukin 5. Annals of Allergy 70: 256-260.

Renzi PM, Du T, Sapienza S, Wang NS, Martin JG 1991. Acute effects of interleukin-2 on lung mechanics and airway responsiveness in rats. Am Rev Respir Dis 143: 380-385.

Renzi PM, Sapienza S, Du T, Wang NS, Martin JG 1991. Lymphokine-induced airway hyperresponsiveness in the rat. Am Rev Respir Dis 143: 375-379.

Renzi PM, Olivenstein R, Martin JG 1993. Inflammatory cell populations in the airways and parenchyma after antigen challenge in the rat. Am Rev Respir Dis 147: 967-974.

Renzi PM, Yang JP, Yasruel Z, Al Assaad S, Hamid Q 1996. Cytokine expression in the presence or absence of late airway responses after antigen challenge of sensitized rats. Am J Respir Cell Mol Biol 15: 367-373.

Robinson DS, Hamid Q, Bentley A, Ying S, Kay AB, Durham SR 1993. Activation of CD4+ T cells increased Th2-type cytokine mRNA expression and eosinophil recruitment in bronchoalveolar lavage after allergen inhalation challenge in patients with atopic asthma. J Allergy Clin Immunol 92: 313-324.

Robinson D, Hamid Q, Ying S, Bentley A, Assoufi B, Durham S, Kay AB 1993. Prednisone treatment in asthma is associated with modulation of bronchoalveolar lavage cell Interleukin-4, Interleukin-5, and Interferon-g cytokine gene expression. Am Rev Respir Dis 148: 401-406.

Robinson DS, Ying S., Bentley AM, Meng Q, North J, Durham SR, Kay AB, Hamid Q 1993. Relationships among numbers of bronchoalveolar lavage cells expressing messenger ribonucleic acid for cytokines, asthma symptoms, and airway methacholine responsiveness in atopic asthma. J Allergy Clin Immunol 92: 397-403.

Robinson DS, Hamid Q, Ying S, Tsicopoulos A, Barkans J, Bentley AM, Corrigan C, Durham SR, Kay AB 1992.Predominant Th2-like bronchoalveolar T-lymphocyte population in atopic asthma. N Engl J Med 326: 298-304.

Rothenberg ME, Ownbey R, Mehlhop PD, Loiselle PM, Vanderijn M, Bonventre JV, Oettgen HC, Leder P, Luster AD 1996. Eotaxin triggers eosinophil-selective chemotaxis and calcium flux via a distinct receptor and induces pulmonary eosinophilia in the presence of interleukin 5 in mice. Molecular Medicine 2: 334-348.

Sanderson CJ 1992. Pharmacological implications of interleukin-5 in the control of eosinophilia. Advances in Pharmacol 23: 163-177.

Sanderson CJ 1992. Interleukin-5, eosinophils, and disease. Blood 79: 3101-3109.

Sakamaki K, Miyajima I, Kitamura T, Miyajima A 1992. Critical cytoplasmic domains of the common beta subunit of the human GM-CSF, IL-3 and IL-5 receptors for growth signal transduction and tyrosine phosphorylation. EMBO Journal 11: 3541-3549.

Satoh T, Sun L, Li MS, Spry CJ 1994. Interleukin-5 mRNA levels in blood and bone marrow mono- 
nuclear cells from patients with the idiopathic hypereosinophilic syndrome. Immunol 83: 308-812.

Schrezenmeier H, Thome SD, Tewald F, Fleischer B, Raghavachar A 1993. Interleukin-5 is the predominant eosinophilopoietin produced by cloned $\mathrm{T}$ lymphocytes in hypereosinophilic syndrome. Experimental Hematol 21: 358-365.

Sedgwick JB, Quan SF, Calhoun WJ, Busse WW 1995. Effect of interleukin-5 and granulocyte-macrophage colony stimulating factor on in vitro eosinophil function: comparison with airway eosinophils. J Allergy \& Clin Immunol 96: 375-385.

Sewell WA, Mu HH1996. Dissociation of production of interleukin-4 and interleukin-5. Immunol \& Cell Biol 74: 274-277.

Sur S, Gleich GJ, Swanson MC, Bartemes KR, Broide DH 1995. Eosinophilic inflammation is associated with elevation of interleukin-5 in the airways of patients with spontaneous symptomatic asthma. $J \mathrm{Al}$ lergy \& Clin Immunol 96: 661-668.

Taha R, Kotsimbos T, Song YL, Schotman E, Menzies R, Hamid Q 1997. IFN- $\gamma$ and IL-12 are increased in active vs. non-active pulmonary tuberculosis. Am J. Resp\& Crit Care Med 155: 1135-1139.

Takagi M, Hara T, Ichihara M, Takatsu K, Miyajima A 1995. Multi-colony stimulating activity of interleukin 5 (IL-5) on hematopoietic progenitors from transgenic mice that express IL-5 receptor alpha subunit constitutively. J Exp Med 181: 889-899.

Takai S, Yamada K, Hirayama N, Miyajima A, Taniyama T 1994. Mapping of the human gene encoding the mutual signal-transducing subunit (beta-chain) of granulocyte-macrophage colony-stimulating factor (GM-CSF), interleukin-3 (IL-3), and interleukin-5 (IL-5) receptor complexes to chromosome 22q13.1. Human Genetics 93: 198-200.

Takaki S, Murata Y, Kitamura T, Miyajima A, Tominaga A, Takatsu K 1993. Reconstitution of the functional receptors for murine and human interleukin 5.J Exp Med 177: 1523-1529.

Tavernier J, Tuypens T, Plaetinck G, Verhee A, Fiers W, Devos R 1992. Molecular basis of the membraneanchored and two soluble isoforms of the human interleukin 5 receptor subunit. Proc Natl Acad Sci 89: 7041-7045.

Tavernier J, Devos R, Cornelis S, Tuypens T, Van der Heyden J, Fiers W, Plaetinck G 1991. A human high affinity interleukin-5 receptor (IL-5) is composed of an IL-5-specific $\alpha$ chain and a $\beta$ chain shared with the receptor for GM-CSF. Cell 66: 1175-1184.

Till S, Li B, Durham S, Humbert M, Assoufi B, Huston D, Dickason R, Jeannin P, Kay AB, Corrigan C 1995. Secretion of the eosinophil-active cytokines interleukin-5, granulocyte/macrophage colonystimulating factor and interleukin-3 by bronchoalveolar lavage CD4+ and CD8+ T cell lines in atopic asthmatics, and atopic and non-atopic controls. Eur J Immunol 25: 2727-2731.

Tuypens T, Plaetinck G, Baker E, Sutherland G, Brusselle G, Fiers W, Devos R, Tavernier J 1992. Organization and chromosomal localization of the human interleukin 5 receptor alpha-chain gene. Euro
Cytokine Network 3: 451-459.

Van der Bruggen T, Caldenhoven E, Kanters D, Coffer P, Raaijmakers JA, Lammers JW, Koenderman L 1995. Interleukin-5 signaling in human eosinophils involves JAK2 tyrosine kinase and Stat1 alpha. Blood 85: 1442-1448.

Van Oosterhout AJ, Ladenius AR, Savelkoul HF, Van Ark I, Delsman KC, Nijkamp FP 1993. Effect of anti-IL-5 and IL-5 on airway hyperreactivity and eosinophils in guinea pigs. Am Rev Respir Dis 147: $548-552$

Van Oosterhout AJ, Fattah D, Van Ark I, Hofman G, Buckley TL, Nijkamp FP 1995. Eosinophil infiltration precedes development of airway hyperreactivity and mucosal exudation after intranasal administration of interleukin-5 to mice. J Allergy \& Clinical Immunol 96: 104-112.

Van Straaten JF, Dokter WH, Stulp BK, Vellenga E 1994. The regulation of interleukin 5 and interleukin 3 gene expression in human T cells. Cytokine 6: 229-234.

Walker C, Bauer W, Braun RK, Menz G, Braun P, Schwarz F, Hansel TT, Villiger B 1994. Activated T cells and cytokines in bronchoalveolar lavages from patients with various lung diseases associated with eosinophilia. Am J Respir Critical Care Med 150: 1038-1048.

Walker C, Bode E, Boer L, Hansel TT, Blaser K, Virchow JC Jr 1992. Allergic and nonallergic asthmatics have distinct patterns of T-cell activation and cytokine production in peripheral blood and bronchoalveolar lavage. Am Rev Respir Dis 146: 109-115.

Walker C, Kaegi MK, Braun P, Blaser K 1991. Activated $\mathrm{T}$ cells and eosinophilia in bronchoalveolar lavages from subjects with asthma correlated with disease severity. J Allergy Clin Immunol 88: 935-942.

Watanabe A, Rossi P, Renzi PM, Xu LJ, Guttmann RD, Martin JG 1995. Adoptive transfer of allergic airway responses with sensitized lymphocytes in $\mathrm{BN}$ rats. Am J Respir \& Critical Care Med 152: 64-70.

Watanabe A, Mishima H, Renzi PM, Xu LJ, Hamid Q, Martin JG 1995. Transfer of allergic airway responses with antigen-primed CD4+ but not CD8+ T cells in brown Norway rats. J Clin Invest 96: 1303 1310.

Watanabe A, Mishima H, Kotsimbos ATC, Renzi PM, Martin JG, Hamid Q 1997. Adoptively transferred late allergic airway responses are associated with $\mathrm{Th} 2$ type cytokines in the rat. Am J Respir Crit Care Med 16: 69-74.

Weller PF 1992. Cytokine regulation of eosinophil function. Clinical Immunol \& Immunopathol 62: S55-59.

Wiggs BR, Bosken C, Paré PD, Hogg JC 1992. A model of airway narrowing in asthma and in chronic obstructive pulmonary disease. Am Rev Respir Dis 145: 1251-1258.

Yamagata T, Nishida J, Sakai R, Tanaka T, Honda H, Hirano N, Mano H, Yazaki Y, Hirai H 1995. Of the GATA-binding proteins, only GATA-4 selectively regulates the human interleukin-5 gene promoter in interleukin-5-producing cells which express multiple GATA-binding proteins. Molecular \& Cellular Biology 15: 3830-3839. 
Yamaguchi S, Nagai H, Tanaka H, Tsujimoto M, Tsuruoka N. 1994. Time course study for antigeninduced airway hyperreactivity and the effect of soluble IL-5 receptor. Life Sciences 54: 471-475.

Yamaguchi, Y, Hayashi Y, Sugama Y, Miura Y, Kasahara T, Kitamura S, Torisu M, Mita S, Tominaga A, Takatsu K, Suda T 1988. Highly purified murine interleukin-5 (IL-5) stimulates eosinophil function and prolongs in vitro survival. J Exp Med 167:17371742.

Yamaguchi N, Hitoshi Y, Takaki S, Murata Y, Migita M, Kamiya T, Minowada J, Tominaga A, Takatsu K 1991. Murine interleukin 5 receptor isolated by immunoaffinity chromatography: comparison of determined $\mathrm{N}$-terminal sequence and deduced primary sequence from cDNA and implication of a role of the intracytoplasmic domain. Internat Immunol 3: 889-98.

Yang LP, Byun DG, Demeure CE, Vezzio N, Delespesse G 1995. Default development of cloned human naive CD4 T cells into interleukin-4- and interleukin5- producing effector cells. Eur J Immunol 25: 3517 3520.

Yasruel Z, Humbert M, Kotsimbos ATC, Ploysongsang Y, Minshall E, Durham S, Pfister R, Menz G, Tavernier J, Kay AB, Hamid Q 1997. Expression of membrane-bound and soluble interleukin-5 alpha receptor mRNA in the bronchial mucosa of atopic
\& non-atopic asthmatics. Am J Resp Crit Care Med 155: 1413-1418.

Ying S, Durham SR, Corrigan CJ, Hamid Q, Kay AB 1995. Phenotype of cells expressing mRNA for TH2type (interleukin 4 and interleukin 5) and TH1-type (interleukin 2 and interferon gamma) cytokines in bronchoalveolar lavage and bronchial biopsies from atopic asthmatic and normal control subjects. Am J Respir Cell \& Mol Biol 12: 477-487.

Ying S, Durham SR, Barkans J, Masuyama K, Jacobson M, Rak S, Lowhagen O, Moqbel R, Kay AB, Hamid Q 1993. T cells are the principal source of interleukin-5 mRNA in allergen-induced rhinitis. Am J Respir Cell Mol Biol 9: 356-360.

Ying S, Durham SR, Barkans J, Masuyama K, Jacobson M, Rak S, Lowhagen O, Moqbel R, Kay AB, Hamid QA 1993. T cells are the principal source of interleukin-5 mRNA in allergen-induced rhinitis. Am J Respir Cell Mol Biol 9: 356-360.

Zanders ED 1994. Interleukin-5 receptor alpha chain mRNA is downregulated by transforming growth factor- $\beta 1$. Soluble or membrane-anchored? Eur Cytokine Network 5: 419-422.

Zon LI, Yamaguchi Y, Yee K, Albee EA, Kimura A, Bennett JC, Orkin SH, Ackerman SJ 1993. Expression of mRNA for the GATA-binding proteins in human eosinophils and basophils: potential role in gene transcription. Blood 81: 3234-3241. 